\title{
REGULATORY AND OPERATIONAL COMPONENTS IN THE PROFESSIONAL JOURNALISTS' TRAINING AT THE AMERICAN AND UKRAINIAN UNIVERSITIES: COMPARATIVE ASPECT
}

The article dwells upon the comparative aspect of regulatory and operational components during the professional journalists' training at the American and Ukrainian universities. Peculiarities of regulatory aspect of professional journalists 'training in both countries have been provided. Outcomes, obtained by would be specialists in journalism have been characterized. Educational standards and legal framework of the researched countries have been described. It has been revealed that the professional training of media specialists in the USA is based on the principles of social justice, honesty and morality; compliance with legislation, code of ethics, while in Ukraine it is carried out in accordance with the legal framework of higher education. Based on the results of comparative analysis of regulatory component it has been outlined that the professional journalists' training in the US because of decentralization is characterized by the absence of unified qualification framework system. It has been also identified that the professional journalists' training in the USA and Ukraine is subordinated to the demands of labour market.

The operational component of professional journalists' training of both countries has been analyzed. Common and distinctive peculiarities of the operational component have been determined. Traditional and innovative methods, applied during the professional training of future specialists in journalism at the higher education institutions of the US and Ukraine have been considered. It has been outlined such traditional methods applied during the professional journalists'training in both countries: seminars, lectures, practical, laboratory classes, independent work and control activities. On the basis of the scientific research it has been proposed to implement innovative methods of studying in the higher education of Ukraine.

Key words: university, USA, Ukraine, professional training, operational component, regulatory framework, journalism.

It is necessary to point out that globalized processes in economy, modernization of production, development of information and communication technologies, rapid and dynamic changes in the labour market are associated with Ukraine's integration into the European and global space, and determine the need for highly qualified specialists in journalism. At the present stage of the development of society journalism is considered one of the most significant branches of education. Thus, it is possible to note the main mission of a journalist is to serve society through the demonstration of ethical, moral and social values; truthful news reporting; protection of national interests, traditions and culture, etc. It is also important to emphasize on the fact that foreign experience, in particular, the US is interesting for domestic institutions of Ukraine, as in recent years in the United States there have been significant changes in the education system that can be used in Ukraine. That is why the comparative and pedagogical analysis of professional training of journalists in Ukraine and the USA is relevant in the educational process.

The peculiarities of professional journalists' training at Ukrainian universities are the subject of the study of domestic scientists: V. Zdorovega, I. Mykhailyn and V. Rizun. The methodology of studying in higher education institutions of Ukraine has been analyzed in the works of M. Nechytalyuk, L. Pukhovska, M. Bratko, P. Saukh, O. Stoyka, T. Olender and others. In recent years comparative and pedagogical studies of various aspects of education abroad, including globalization and integration processes, have been elaborated by N. Bidyuk, E. Brazhnik, O. Barabash, M. Busko, K. Istomina, N. Mukan \& Yu. Shiyka, I. Lytovchenko, O. Lokshina, A. Sbrueva, S. Sysoeva, S. Tsura. Comparative pedagogy research on the US higher professional education has been carried out by Ukrainian scholars M. Bratko, I. Kozubovska \& O. Stoika, O. Lutsenko \& L. Polyvana, O. Tarasova, M. Vachevskyy, S. Vitvytska.

The purpose of the article is to conduct a comparative analysis of the regulatory and operational component of the professional journalists' training at the US and Ukrainian universities.

To start with, it is significant to state that a comparative analysis of the professional journalist's training at the US and Ukrainian universities was carried out on the basis of identifying common and distinctive peculiarities in the journalism educational system, focusing mainly on regulatory and operational components. In our opinion, the implementation of the US progressive ideas and their comparison with the traditions of Ukrainian domestic universities will help to improve the training of specialists in the field of journalism at Ukrainian universities.

On the basis of the analysis of the US higher education system, it should be noted that university activities, training of future journalists are subject to labour market conditions. Accordingly, the factors that determine students' choice of higher education institution affect universities much more than government regulation. The scientist Ewell indicates the shortcomings of the market system, so it is important for the American education system to move to another indicator of quality, namely the learning outcomes of journalist students [6, p. 84].

Thus, it has been considered that one of the best tools for ensuring the quality of the US education is the National Survey of Student Engagement, which identifies factors in the learning experience of future journalism professionals. However, survey-based statistics are inaccurate and cannot be the basis for making important decisions and funding US higher education institutions. Therefore, it is important to improve these statistics in order to influence the free choice of the institution by journalists, or actively use it as an indicator that will increase the level of teaching and learning in low-performing US higher establishments [6, p. 85]. 
According to the statistical data of the labour market for the period 2016-2026 it is expected the level of employability of future journalists in the position of reporter, correspondent, radio analysts will be reduced to $9 \%$, while the number of employed technical writers and specialists in public relations is projected to increase [9].

It has been stated that declining revenues from advertising in radio, newspapers and television will have a negative impact on employment growth for these professions. The number of readers and distribution of newspapers is also expected to decline over the next decade. In addition, television and radio stations will increasingly publish content online and on mobile devices. As a result, news organizations may have trouble selling traditional forms of advertising, which are often seen as their main source of income. Some organizations are likely to continue to use new forms of advertising or offer paid subscriptions, but these innovations will not be able to compensate for lost advertising revenue. Declining incomes will force news organizations to reduce the number of hired journalists. However, the growing demand for online news will be able to offset some of the cuts.

Analyzing conditions of the US labour market, it has been noted that news organizations more often share resources, staff and content with other media. For example, journalists may collect and report on news for the media that may be published in several newspapers owned by the same company. As a result of consolidation and news exchange, the demand for future journalism professionals will decrease. However, in some cases, consolidation helps to limit job losses: newspapers, radio and television stations that face financial problems are able to retain staff at the expense of other organizations. That is why journalist students look for a job in the position of a reporter, correspondent and news analyst. Multimedia journalism covers the recording and editing of video or audio materials, and should therefore also focus on improving the practical skills of future journalism professionals. Because of the fact that stations and media publish content on multiple media platforms, especially the Internet; employers will prefer candidates with experience in developing and coding web resources.

On the basis of this research it has been concluded that Ukrainian institutions likewise the US, must be subject to labour market conditions, but employers are not sufficiently aware of the existence of the National Qualifications Framework. Familiarizing with this document, employers claim that the level of knowledge, skills and abilities of young journalists, unfortunately, does not meet the requirements of society due to the fact curricula is based on a big amount of theoretical disciplines [2].

Considering the regulatory framework, we can say that the journalists' training at the US universities is based on the principles of social justice, honesty and morality; compliance with legislation, code of ethics, etc. [5]. «Bilingual Education Act», «Amendment No. 10 to the Constitutional Act», Higher Education Act, Act National Defense Education Act, and Equal Access Act are considered the main documents that regulate the US higher education.

In Ukraine, on the other hand, the training of future journalism specialists is carried out in accordance with regulatory framework of higher education. The main regulatory documents of Ukrainian higher education system are: laws «On Higher Education», «On Professional and Technical Education», methodological recommendations developed to implement the order of the Ministry of Education and Science No. 943 of 16.10.2009 «On introduction of the European credit transfer system in higher educational institutions of Ukraine», Decree of the President of Ukraine of June 25, 2013 No. 344/2013, «On the National Strategy for the Development of Education in Ukraine until 2021», etc.

In accordance with Article 5 of the Law of Ukraine «On Higher Education» No. 2145-VIII of 05.09.2017, professional training of journalists is carried out at the appropriate levels of higher education: initial level (short cycle) - junior bachelor, first level (Bachelor), second Master's degree), third degree (educational-scientific or educational-creative) and degrees of higher education: junior bachelor, bachelor, master, doctor of philosophy, doctor of sciences, which correspond to the qualification levels of the National Qualifications Framework (NQF). Positive changes in the legislation of Ukraine are the renewal of the National Qualifications Framework [4], which will foster the involvement of students and teachers into international mobility and respect for culture and values of other countries.

It is also important to emphasize the fact that Ukraine is involved in the draft of European Qualifications System, the main elements of which are: a «coordinate system» in which learning outcomes are distributed according to eight levels and intended for individual citizens: European Credit Transfer System, Europass document, Ploteus database, which contains a list of learning opportunities; general principles of quality assurance, official recognition of documents on education and key competencies [3, p. 5-10].

In comparison to Ukraine, the United States is characterized by decentralization that is why there is no single unified qualifications framework. In 2011, the American Lumina Foundation proposed The Degree Qualification Profile for the US higher education system. This document provides data on education levels: junior specialist (twoyear college graduate), Bachelor (120-160 ECTS credits), Master's degree (30-50 ECTS credits), Doctor of Philosophy (60-80 ECTS credits); a clear description of the skills and competencies that future journalists will acquire during their studies, gaining a certain qualification level; student learning outcomes in five interrelated categories: specialized knowledge; broad and integrative knowledge; intellectual skills; applied and collaborative learning; civic and global learning [7, p. 5-12].

Thus, it is necessary consider the results of bachelor's degree in journalism based on these categories. According to the above information, the first category is the acquisition of professional knowledge by future professionals in the field of journalism, namely students learn how to define and explain the structure, style and features of special- 
ized disciplines, using professional terminology, tools, technologies and methods; explore the problem of the journalistic industry, offering their own ideas and concepts for its solution, etc.

The second category is broad and comprehensive knowledge: students are able to create research and creative projects related to current events in the field of journalism. Intellectual skills include the ability of students to think analytically, to use information sources correctly, to perceive the world through the prism of other people, to follow the rules of the code of ethics in various situations.

The fourth category is applied and group training: future specialists analyse current problems, prepare a project, demonstrate their knowledge, and discuss the problem in groups, summarizing its importance in society.

The fifth category is social and global learning: students gain knowledge about various cultural, economic, political aspects of media; cooperate with public organizations; learn to identify important issues that affect the development of the country, continent, culture; assess the role of non-governmental and intra-governmental organizations in solving public problems [7, p. 13-18].

As it has been researched, the United States presents a classic example of a decentralized education system, so it is characterized by the absence of state standard for the training of undergraduate journalism students. Each state has its own regulations governing the education sector; determine the term and content of education, the conditions of enrolment in an educational institution and the requirements for obtaining an educational level [8].

In Ukraine, according to the field standard of higher education for the specialty «Journalism», the future specialist in journalism must perform complex tasks and solve problems in the field of social communications, which involves conducting innovative research in professional activities and mastering the basic methods, tools and technologies used in journalism. The main responsibilities of a journalist are: to promptly edit texts in accordance with language norms; filling the rubric with material in accordance with the established norms of law and ethics; constant monitoring of Internet publications, print media and television; checking the accuracy of the received information in accordance with the legislation on mass media; promotion of media product on social networks; coordination of work of system analysts, programmers and other specialists, etc. [1].

As a result of the analytical analysis of the regulatory component of the USA and Ukraine, common peculiarities have been discovered, which consists in describing journalism as a subject field branch, the list of professional and general competences, learning outcomes. However, it is evident that the draft standard of Ukraine, in relation to the United States, is not characterized by a significant level of interdisciplinary and variability, and also does not provide detailed information about teaching methods.

Analysing theoretical foundations and scientific and methodological basis of professional training of bachelors in journalism at US universities, it is necessary to point out the membership in world trade unions and organizations: International Federation of Journalists, International Association of Journalists, the International Press Association, the Global Investigative Journalism Network, and the National Centre for Business Journalism, the Center for Media Literacy, and the Strategies for Media Literacy, National Alliance for Media Arts and Culture.

The following unions and public organizations operate in Ukraine: the Association of European Journalists, the National Union of Journalists of Ukraine, the Ukrainian Media Association, etc. Comparing the activities of associations in both countries, we can say that media organizations in the United States includes prominent scholars and educators, while in Ukraine such organizations are unions and public associations, which are usually created at the initiative of activists and scholars. It should be noted that domestic universities are members of Ukrainian educational organizations.

In the United States, the results of journalism research are published in the following journals: «American Journalism, «Journalism \& Mass Communication», «The Voice of Journalism», «Journalism education», «Journalism studies». These journals cover important aspects and features of the development of journalism education.

In Ukraine, the results of scientific research in the field of journalism are mostly published in professional journals, which include bulletins of the Institute of Journalism of Taras Shevchenko National University of Kyiv «Journalism», «Current issues of mass communication», «Information Society»; «Bulletin of Lviv University. I. Franko «Journalism», «TV and Radio Journalism», Bulletin of Odessa National University I. Mechnikov «Dialogue: Media Studios», Bulletin of Kharkov National University «Social Communications». These journals are published in Ukrainian and are not included in international scientometric databases, which limit the dissemination of scientific research results outside Ukraine.

On the basis of the study of higher education in the United States, the following features have been identified: the autonomy of the universities, which leads to the lack of uniform criteria for the selection of students; system of self-assessment and self-regulation by universities of the educational quality process. According to the analysed data, it was found that important components of professional training of journalists are communicative and cultural competences, which contribute to the improvement of human relations, development of creative personality, formation of ethnic stereotypes aimed at assimilation and analysis of information from various resources.

Compared to the United States, the system of professional training of journalists in Ukraine is based on the competence approach: employers are satisfied with the level of theoretical knowledge of freelance students, but note the lack of practical experience. Instructional programs in Journalism in Ukraine are created in accordance with modern educational standards and qualifications, approved by the Law of Ukraine «On Higher Education». The main requirements for the structure of instructional programs for bachelors in journalism, which contribute to the devel- 
opment of professional training are: the introduction of new concepts, principles, concepts, approaches; comparison of learning outcomes according to qualification levels; introduction of a competency-based approach based on the ability to use knowledge, skills and abilities in work and study situations; achieving flexibility and responding to student needs; development of university autonomy.

Comparing the operational component of bachelor's degree in journalism at the universities of Ukraine and the United States, it has been investigated that the educational process is conducted in the forms seminars, lectures, practical, laboratory classes, independent work and tests. It should be noted that the number of classroom hours at the US universities during the process of training bachelors in journalism is much smaller (approximately $20 \%$ ) than at Ukrainian universities. This is due to the fact that at the US universities, $80 \%$ is allocated to independent student work (writing a research paper, implementing individual tasks). A distinctive feature is the method of conducting lectures in researched countries. In the United States, lectures are based on a student-centered approach, according to which the student is an active participant in the educational process, while at the higher institution of Ukraine the teacher is an active speaker and students are passive recipients.

Analyzing the methods of teaching in the process of professional journalists at the universities of the USA and Ukraine, it has been noted that traditional methods of teaching journalism such as visual, verbal and practical, prevail at higher establishments of Ukraine. Instead, innovative teaching methods that promote critical and analytical thinking are dominated at the USA. «Field training», problem-solving method «case study», «brainstorming», service community learning are among the popular methods of active training of bachelors in journalism in the United States.

Taking into account the comparative analysis of regulatory and operational component, it is important to draw the conclusion that the United States has developed an effective model for professional journalists' training which is based on achieving high learning outcomes in accordance with educational standards and qualification levels. It has been also pointed out the significant impact of new technologies, globalization and integration processes leads to the obligatory reform of Ukrainian higher education and the reassessment of journalists' training system.

\section{Bibliography}

1. Галузевий стандарт. 2019. URL: https://mon.gov.ua/storage/app/media/vishcha-osvita/zatverdzeni\%20standarty/ 2019/06/25/061-zhurnalistika-bakalavr.pdf.

2. Гриненко І. В., Рибак С. С., Хлєбнікова Н. В., \& Хоменко С. А. Як ринок праці розуміє загальні і спеціальні компетентності журналістів. Український гуманітарний інститут, 2017. URL: https://detector.media/withoutsection/ article/125593/2017-05-01-yak-rynok-pratsi-rozumiie-zagalni-i-spetsialni-kompetentnosti-zhurnalistiv.

3. Захарченко В. М., Луговий В. І., Рашкевич Ю. М., Таланова Ж. В. Розроблення освітніх програм. Методичні рекомендації. / В. Г. Кремень (ред.). Київ : ДП «НВЦ «Пріоритети», 2014. 32 с.

4. Закон України «Про освіту». 2018. URL: https://zakon.rada.gov.ua/laws/show/2145-19.

5. College of Professional Studies and Fine Arts. URL: https://psfa.sdsu.edu/about_us/strategic plan.

6. Ewell P. T. The US National Survey of Student Engagement (NSSE). Public Policy for Academic Quality: Analyses of Innovative Policy Instruments. Dordrecht, Netherlands: Springer, 2010. Pp. 83-97.

7. The Degree Qualifications Profile. A learning centered framework for what college graduates should know and be able to do to earn the associate, bachelor's or master's degree. Indiana Polis : Lumina Foundation, 2014. 55 p.

8. U.S. Department of Education. National Advisory Committee on Institutional Quality and Integrity. URL: https://sites.ed.gov/ naciqi/.

9. U.S. Labour Statistics Security Statement. URL: https://www.bls.gov.

\section{References:}

1. Haluzevyi standart (2019) [Field standard]. URL: https://mon.gov.ua/storage/app/media/vishcha-osvita/zatverdzeni\%20 standarty/2019/06/25/061-zhurnalistika-bakalavr.pdf. [in Ukrainian]

2. Hrynenko I. V., Rybak S. S., Khliebnikova N. V., \& Khomenko S. A. (2017) Yak rynok pratsi rozumiie zahalni i spetsialni kompetentnosti zhurnalistiv. [How the labour market understands the general and special competences of journalists]. Ukrainskyi humanitarnyi instytut. URL: https://detector.media/without section/article/125593/2017-05-01-yak-rynok-pratsi-rozumiiezagalni-i-spetsialni-kompetentnosti-zhurnalistiv [in Ukrainian]

3. Zakharchenko V. M., Luhovyi V. I., Rashkevych Yu. M., Talanova Zh. V. (2014) Rozroblennia osvitnikh prohram. Metodychni rekomendatsii [Elaboration of educational programs. Guidelines]. V. H. Kremen (red.). Kyiv: DP «NVTs «Priorytety». 32 s. [in Ukrainian]

4. Zakon Ukrainy «Pro osvitu» (2018) [Law of Ukraine «On Education»]. URL: https://zakon.rada.gov.ua/laws/show/2145-19 [in Ukrainian]

5. College of Professional Studies and Fine Arts. URL: https://psfa.sdsu.edu/about_us/strategic plan.

6. Ewell P. T. (2010) The US National Survey of Student Engagement (NSSE). Public Policy for Academic Quality: Analyses of Innovative Policy Instruments. Dordrecht, Netherlands: Springer. Pp. 83-97.

7. The Degree Qualifications Profile (2014) A learning centered framework for what college graduates should know and be able to do to earn the associate, bachelor's or master's degree. Indiana Polis: Lumina Foundation. P. 55.

8. U.S. Department of Education. National Advisory Committee on Institutional Quality and Integrity. URL: https://sites.ed.gov/ naciqi/.

9. U.S. Labour Statistics Security Statement. URL: https://www.bls.gov. 
Марціхів Х. Р. Порівняльний аспект нормативно-правового та операційного компонентів у процесі професійної підготовки журналістів в університетах США і Украӥни

Стаття присвячена порівняльному аналізу нормативно-правового та операційного компонентів професійної підготовки журналістів в університетах США та Украӥни. Охарактеризовано особливості нормативно-правового забезпечення професійної підготовки журналістів в обох краӥнах. Виокремлено результати навчання, які студентижурналісти отримають під час професійної підготовки. Описано освітні стандарти та законодавчу базу досліджуваних краӥн. Виявлено, щзо професійна підготовка майбутніх медіаспещіалістів у США базується на принщипах соиіальної справедливості, чесності та моралі, дотриманні законодавства, етичного кодексу, натомість в Україні здійснюється відповідно до законодавчої бази вищої освіти.

На основі результатів порівняльного аналізу нормативно-правового складника зазначено, що професійна підготовка журналістів у США через децентралізовану систему управління характеризується відсутністю єдиної системи кваліфікаційних рамок. Також було встановлено, щео професійна підготовка журналістів у США та Україні підпорядковується вимогам ринку праці.

Проаналізовано операційний складник професійної підготовки журналістів в обох країнах. Визначено спільні та відмінні особливості операційного компонента. Розглянуто традиційні та інноваційні методи, щчо застосовуються nід час професійної підготовки майбутніх фахівиів з журналістики у вищих навчальних закладах США та України. Виокремлено такі традиційні методи, які застосовуються під час професійної підготовки журналістів в обох краӥнах, як: семінари, лекиії, практичні заняття, лабораторні заняття, самостійна робота та контрольна діяльність. Розглянуто ефективність застосування активних методів навчання у процесі професійної підготовки майбутніх фахівців з журналістики. На основі порівняльно-педагогічного аналізу запропоновано впроваджувати інноваційні методи навчання у систему вищої освіти Украӥни.

Ключові слова: університет, США, Украйна, професійна підготовка, операційний компонент, нормативноправовий компонент, журналістика. 